\title{
Why do academics engage with industry? The entrepreneurial university and individual motivations
}

Pablo D’Este ${ }^{\mathrm{a}}$, Markus Perkmann ${ }^{\mathrm{b}}$

${ }^{\mathrm{a}}$ INGENIO

Universidad Politecnica de Valencia

Ciudad Politecnica de la Innovacion - Edif 8E 4

Camino de Vera s/n

46022 Valencia

T: +34963877 007 ext: 77048

E: pabdescu@upvnet.upv.es

${ }^{\mathrm{b}}$ Imperial College London

Business School

South Kensington Campus

London SW7 2AZ

T: +44 2075941955

E:m.perkmann@imperial.ac.uk

Corresponding author: Pablo D’Este

\begin{abstract}
The debate on the entrepreneurial university has raised questions about what motivates academics to engage with industry. This paper provides evidence, based on survey data for a comprehensive sample of UK investigators in the physical and engineering sciences. Our results suggest that most academics engage with industry to further their research rather than to commercialize their knowledge. However, there are differences in terms of the channels of engagement. While patenting and spin-off company formation is motivated exclusively by commercialization, joint research, contract research and consulting are strongly informed by research-related motives. We conclude that policy should refrain from focusing on monetary incentives for industry engagement and consider a broader range of incentives for promoting interaction between academia and industry.
\end{abstract}

Keywords: University-industry relations - joint research - collaborative research patenting - commercialization 


\section{Introduction}

The 'entrepreneurial university’ is in vogue (Etzkowitz, 2003; Slaughter and Leslie, 1997). Proponents of the entrepreneurial university claim that universities are being transformed from ivory towers to engines of economic growth (Feller, 1990; Florida and Cohen, 1999). In similar vein, others argue that universities and industry are converging towards a hybrid order where the differences between scholarly and commercial logics are becoming blurred (Owen-Smith, 2003). Policy-makers in a number of countries are promoting such developments by encouraging collaboration between academia and industry (Mowery and Nelson, 2004). Implicit in many accounts of the entrepreneurial university is the assumption that academic researchers engage with industry in order to commercialize their knowledge. Thus, policy-makers are providing monetary incentives to facilitate their commercial involvement (Lach and Schankerman, 2008).

In this paper, we investigate whether this assumption about the entrepreneurial academic is backed by evidence on academics’ motivations for engagement with industry. We present the results of a large scale survey of physical and engineering faculty at UK universities. We find, first, that commercialization ranks as the least important motivation for engaging with industry, and that research-related reasons dominate. Thus, it would seem that academics engage with industry mainly to support their academic research activities. Second, we find that the academics’ motivations differ depending on the channel of engagement. We examine both classic technology transfer mechanisms, including patenting and spin-off companies, and more collaborative modes of interaction, including joint research, contract research and consulting. While patenting and spin-off involvement are motivated by commercialization, engagement in collaborative interaction is dominated by researchrelated motivations, including learning from industry and fund-raising. 
Our analysis contributes to the debate on the entrepreneurial university by shedding light on its micro-foundations (Jain et al., 2009). It is important for universities and policy-makers to understand the individual motivational drivers for university-industry relations. Our discussion suggests that undue policy emphasis on commercialization obscures the fact that industry engagement often generates considerable benefits for academic research. We conclude that, given academics’ motivations, to talk of convergence between scholarship and commerce may be premature, although interaction between these realms continues to be mutually beneficial.

The paper is structured as follows. Drawing on the existing literature, we outline the debate on the entrepreneurial university. By giving a voice to both its proponents and critics, we identify questions that have been left unanswered and formulate our research questions. We present survey data from a sample of UK academics, which enable us to investigate their reasons for engagement with industry and, specifically, whether different channels of engagement are underpinned by different motivations. We conclude by discussing the implications of our results against context of the existing literature, and deriving some policy conclusions.

\section{Conceptual considerations}

\subsection{The entrepreneurial university: Overview and main research questions}

Universities are increasingly being called upon to contribute to economic development and competitiveness (Feller, 1990) and policy-makers have implemented measures aimed at increasing the rate of commercialization of university technology. These measures range from laws governing intellectual property (IP) arising from public research, government funding for university technology transfer offices and promotion of translational research and public-private research partnerships (Mowery and Sampat, 2005; Siegel et al., 2007; Zerhouni, 2003). While not prejudging the effectiveness of these policies, various trends would seem to indicate a growing ambition among 
universities to respond to the call for a greater role in technology development, demonstrated by an increasing propensity among universities to patent (Nelson, 2001; Stiglitz and Wallsten, 1999), increased revenues derived from university licensing (Thursby et al., 2001), increasing numbers of university researchers engaging in academic entrepreneurship (Shane, 2005), a growing share of industry funding in university income (Hall, 2004), and the diffusion of technology transfer offices, industry collaboration support offices and science parks (Siegel et al., 2003).

The growing involvement of universities in technology transfer and commercialization raises questions about their nature and mission (McKelvey and Holmén, 2009). Advocates of the 'triple helix' theory claim that universities have embraced economic and social development as a new mission, in addition to their traditional missions of teaching and research (Etzkowitz, 1998). In embracing this new task, universities are becoming part of a coherent system that includes industry and government and underpins innovation and economic progress (Etzkowitz and Leydesdorff, 2000). Implicit in this view is that the role of academics is shifting. Rather than concentrating on 'blue-skies' research, academics are seen increasingly to be eager to bridge the worlds of science and technology, in an entrepreneurial way, by commercializing the technologies that emerge from their research (Clark, 1998; Etzkowitz, 2003; Shane, 2004).

By actively engaging in technology development, universities are demonstrating ambidexterity in their ability to produce both scientific knowledge and technology outputs (Ambos et al., 2008). In an analysis of the publishing and patenting activities of the most research-intensive US universities, Owen-Smith (2003) finds there is convergence towards a 'hybrid system' linking scientific and technological success. Specifically, he shows that academic success drives technological invention while advantages in technological invention are driven by organizational learning relating to 
procedures and organizational arrangements for identifying, protecting and managing IP. Over time, positive feedback loops between the two realms lead to a hybrid order where the best universities excel in scientific research and technology commercialization (Owen-Smith, 2003).

Critics have responded by underlining the potentially detrimental effects of ‘entrepreneurial’ science on the long-term production of scientific knowledge, voicing fears that academic science is being instrumentalized and even manipulated by industry (Krimsky, 2003; Noble, 1977; Slaughter and Leslie, 1997). Many universities appear to have become 'knowledge businesses' which are focused not so much on generating a public good for a national audience but providing services to specific stakeholders (McKelvey and Holmén, 2009; Vallas and Kleinman, 2008). The perceived risks include a shift in scientific research from basic research towards more applied topics and less academic freedom (Behrens and Gray, 2001; Blumenthal et al., 1986), lower levels of research productivity among academics (Agrawal and Henderson, 2002) and a slowing-down of open knowledge diffusion (Nelson, 2004; Rosell and Agrawal, 2009). Existing empirical research provides little evidence to support the first two of these concerns, but indicates there may be some justification for concerns over open knowledge diffusion, although the evidence is not conclusive.

Academics’ involvement with industry would appear, therefore, to be largely compatible with the continuing generation of scientific output. It is possible that this is because university researchers en masse have not become academic entrepreneurs and sacrificed scientific rigour on the altar of Mammon. In this paper, we adopt this line of reasoning and investigate academics’ motives for engaging with industry. If their engagement with industry is driven by a desire to further their research rather than to exploit their knowledge, then cooperation is unlikely to be driven by entrepreneurialism, which questions the description of the entrepreneurial university and the policy 
measures implemented to promote its existence.

\subsection{Why do academics engage with industry?}

Universities are professional bureaucracies whose members are relatively free to choose the activities that they believe are in the overall interests of the organization (Mintzberg, 1983). Engaging with industry constitutes discretionary behaviour for academics. In addition, many universities have formal policies for encouraging their academic staff to pursue industry assignments for a specified share of their time (Perkmann and Walsh, 2008). Royalty sharing policies at many universities provide incentives for the disclosure of inventions to the university administration (Bercovitz and Feldman, 2008) and subsequent participation of inventors in product development efforts via spin-off companies or licensing (Lowe, 2006).

Deployment of these incentive mechanisms presupposes that academic researchers respond to financial incentives tied to successful commercialization of their ideas. This is implicit in life cycle theories that maintain that junior researchers focus on building reputation in academia and later in their careers capitalize on their expertise by reaching out to industry (Stephan and Levin, 1992; Zuckerman and Merton, 1972). A qualitative study by Owen-Smith and Powell (2001) provides some support for the idea that academics are attracted by monetary profit. The authors find that in the life sciences where patents have higher monetary value - researchers patent to enhance their incomes. In the physical sciences, on the other hand, patenting is less attractive because of lower monetary pay-offs and therefore is pursued primarily to develop relationships with firms, access equipment or exploit other research-related opportunities (OwenSmith and Powell, 2001).

However, there is a range of contributions that suggests that working with industry is not necessarily underpinned by entrepreneurial intentions in the sense of responding to economic opportunities. Bercovitz and Feldman (2008) find that faculty members' 
compliance with entrepreneurial behaviour can be substantial or symbolic. Only under certain conditions - e.g. presence of local entrepreneurial norms - do academics engage in substantial entrepreneurial behaviour as opposed to superficial compliance.

Research on attitudes to academic entrepreneurship present a differentiated picture. Data on US universities indicate that most academics, particularly in the engineering and the applied sciences, are keen on technology transfer activities, but less so on overly commercial schemes such as start-up assistance to new technology firms, and equity investment (Lee, 1996). Faculty in high ranked institutions are less in favour of academic entrepreneurship than academics at lower tier universities although discipline is still a fairly dominant explanatory factor. The main concern of academics is that industry involvement might restrict academic freedom, i.e. the ability to pursue curiosity-driven research without having to consider commercial gain (Lee, 1996). In a related study, academic respondents express significant support for industry collaboration in terms of the benefits related to their research (Lee, 2000). A meta-study shows that academic researchers' attitudes to financial ties with industry sponsors are largely positive, especially when funding is indirectly related to their research, disclosure is agreed upfront, and ideas are freely publicized (Glaser and Bero, 2005). A study of German academic researchers in four disciplines suggests that acquiring additional research funds and learning from industry constitute the main motives for engaging with industry (Meyer-Krahmer and Schmoch, 1998). A survey of Italian academic inventors indicates that patenting is seen as enhancing prestige and reputation and providing new impulses for research, but that personal remuneration is not seen as important (Baldini et al., 2007).

This review of the literature on academic motivation suggests that the reason why many university researchers engage with industry is to further their research rather than to pursue the commercialization of their ideas. Thus, rather than being entrepreneurs, 
many academics are collaborating with industry to support their research. Benefits from industry cooperation include securing funds for graduate students, accessing laboratory equipment, gaining insights applicable to academic research, and supplementing research monies (Mansfield, 1995).

\subsection{Research questions}

Even though the literature sheds light on certain aspects of university-industry engagement, it leaves two questions unanswered. First, attitudinal studies provide respondents' views about industry engagement, but do not connect them with actual collaboration (Glaser and Bero, 2005; Lee, 1996). Second, many studies focus on specific types of academic industry involvement, with a number of contributions investigating academics’ motives for engaging in patenting (Baldini et al., 2007; Moutinho et al., 2007; Owen-Smith and Powell, 2001). However, interactions between universities and industry take multiple forms (Cohen et al., 2002) and channels of cooperation range from inter-organizational relationships (e.g. joint research or contract research) to spin-off companies, to IP transfer including patenting and licensing (Bercovitz and Feldman, 2006; Bonaccorsi and Piccaluga, 1994; Carayol, 2003; Cohen et al., 2002; D'Este and Patel, 2007; Schartinger et al., 2002). The focus on patenting is a major limitation of these studies as the role of IP rights in transferring knowledge is modest (Agrawal and Henderson, 2002; D'Este and Patel, 2007). At the same time, although the literature on university-industry relationships emphasizes the range of collaboration types (Cohen et al., 2002; Meyer-Krahmer and Schmoch, 1998; Schartinger et al., 2002), it does not examine the rationales underpinning these activities. We need also to know whether the multiplicity of interaction forms is part of a single phenomenon - increasing 'commercialization' of university science - or is indicative of a more heterogeneous reality. Our first research question is:

Q1: What are academic researchers' motivations for engaging with industry? 
Furthermore, given the multi-channel nature of industry collaboration, we also need to examine whether motivations differ among the various channels of interaction.

Attitudinal research shows that academics draw certain 'boundaries' between the forms of industry engagement they see as legitimate, and others that they view as overly commercial (Lee, 1996). We need to investigate where this boundary lies and how it reflects on academics' motivations to engage with industry.

We can distinguish between two broad types of engagement. On the one hand, there are some classic means of research commercialization, such as patenting and spin-off companies. Involvement in patenting means that the names of academic researchers appear in the list of inventors, in patents held by individuals, universities, firms or other organizations. While patenting may not necessarily involve direct collaboration with industry, it indicates an interest in industry problems and applications (Zucker et al., 1998). Thus, patenting can be seen as a form of industry engagement. In the case of spin-off companies, academics establish financial ties with for-profit firms, providing the opportunity for economic participation in the commercialization of technology (Pirnay et al., 2003).

On the other hand, working with industry can involve collaboration through joint research, contract research and consulting. Joint (or collaborative) research among academic and industry researchers is widespread (Perkmann and Walsh, 2007). Contract research refers to industry commissioned applied research carried out by university researchers. Consulting involves application-oriented research or advice, commissioned and funded by industry, and provided by academics (Perkmann and Walsh, 2008). Thus, our second research question is:

Q2: What are academics’ motivations for their engagement with industry through different channels?

The empirical study in this paper is designed to provide answers to these two questions. 
Our analysis is based on survey data collected from physical and engineering science faculty at UK universities, and investigates their motivations to engage in the channels of collaboration described above. Our research design allows us to compare directly academics’ motivations for involvement with industry, across different types of engagement.

Section 3 describes the data and research methodology; Section 4 presents our findings and Section 5 discusses the implications of our study.

\section{Data and main variables}

\subsection{Sample and data collection}

Our data are derived from a large-scale survey of university researchers aimed at obtaining information on their interactions with industry. The sample was compiled from the record of holders of research grants from the UK’s Engineering and Physical Sciences Research Council (EPSRC) between 1999 to 2003. The EPSRC provides research funding mainly to university-based investigators based on applications submitted in response to open calls. It distributes $20-25 \%$ of the total UK public science budget. The EPSRC actively encourages partnerships between researchers and the potential users and beneficiaries of research, such as industry, government, National Health Service (NHS) trusts and non-profit organizations. Almost 45\% of EPSRCfunded projects involve partnerships with industry or other stakeholders.

To ensure our sample was representative of the population of researchers in the physical and engineering sciences, we excluded disciplines whose researchers might be likely to apply to other research councils. The ten disciplines considered in our study are: Chemical Engineering; Chemistry; Civil Engineering; Computer Science; Electrical and Electronic Engineering; General Engineering; Mathematics; Mechanical, Aeronautics and Manufacturing Engineering; Metallurgy and Materials; and Physics. The sample includes 4,337 researchers, corresponding to approximately $42 \%$ of the population of 
active researchers in our target disciplines. ${ }^{1}$

Generalization of our results to the whole population of university researchers should be made with care for three reasons. First, our sample excludes the life sciences and medicine, where university-industry collaboration traditionally plays an important role. Second, even for disciplines within the EPSRC remit, it does not capture researchers relying solely on other forms of funding (e.g. from industry). Third, since our surveyed population includes only grant recipients this might bias the sample towards particularly successful and/or comparatively senior researchers.

The survey was administered by post in 2004 and generated 1,528 returned and valid questionnaires, a response rate of $35.2 \%$. Our tests for response bias indicate that there are no statistically significant differences among response rates across scientific disciplines. ${ }^{2}$ However, there are statistically significant differences with respect to certain individual characteristics, including the proportion of respondents and nonrespondents holding collaborative grants over the period 1991-2003 (57\% and 53\% for respondents and non-respondents, respectively), and being a professor (44\% and 39\% for respondents and non-respondents, respectively). Overall, though, response rate biases are relatively minor and unlikely to affect the results.

The questionnaire contained questions on various aspects of industry engagement. ${ }^{3}$ Our analysis is based on information on the frequency of academic engagement through five channels and respondents' reasons for engagement, gleaned from responses to the question: 'Please rank the following reasons for your involvement in interactions with industry according to their importance' from among 12 items (see Table 1).

\footnotetext{
${ }^{1}$ According to data from the UK 2001 Research Assessment Exercise (RAE)

${ }^{2}$ Response rates (no. of valid returned questionnaires relative to population surveyed) by discipline: Chemical Eng., 35.6\%; Chemistry, 35.9\%; Civil Eng., 35.5\%; Computer Sci., 30.2\%; Electric \& Electronic Eng., 34.7\%; General Eng., 39.7\%; Mathematics, 38.4\%; Mechanical, Aero. \& Manufacturing Eng., 36.9\%; Metallurgy \& Materials, 34.2\%; and Physics, 32.7\%.

${ }^{3}$ See D'Este and Patel (2007) for a detailed description of the questionnaire and survey results.
} 
Respondents were asked to score the importance of each item on a five-point Likert scale, ranging from 'not important' (1) to 'extremely important' (5). We carried out a factor analysis (principal component analysis - PCA) on these 12 items to determine whether they corresponded to more general, underlying rationales for engagement with industry. We refer to these factors as 'motivations'.

We analysed our data via ordered logit regressions, using engagement in various types of channels as the dependent variables.

\subsection{Dependent, explanatory and control variables}

We consider five dependent variables, each representing frequency of industry engagement via a specific channel: joint research agreement, contract research agreement, consulting, spin-off company establishment, and patenting. Respondents were asked: 'How frequently were you engaged in the following types of activity in the calendar years 2002 and 2003?' They were given a choice of five intervals: 0, once or twice, 3 to 5 times, 6 to 9 times, and 10 times or more. ${ }^{4}$ Based on responses, and given that activity was strongly concentrated in the first two interval categories, we defined our dependent variables as ranging between 0 and 2, 0 if the researcher had no involvement for a type of activity, 1 for one or two instances, and 2 if the researcher engaged three or more times in an activity (see descriptive statistics in Table A1 in the Appendix). There is little overlap among these channels, while there is positive and significant bivariate correlation between each pair; Spearman correlation coefficients range from 0.12 to 0.34 . Since our dependent variables are discrete and ordered, we use ordered logit models for our estimations.

The three channels with the highest proportion of researchers engaging at least once are: contract research, joint research, and consulting. More than 50\% of respondents indicated using each of these channels at least once in the period analysed.

\footnotetext{
${ }^{4}$ However, for patents, respondents were requested to report the actual number of patent applications.
} 
We used the motivational factors resulting from our factor analysis as the main explanatory variables (see Table A2 in the Appendix for descriptive statistics). Specifically, we regressed each of the frequency measures on the extent to which respondents assessed each motivation as important. We measured the importance attributed to a specific motivation by taking the average score of each respondent's assessment of the importance of the single incentive items that composed each motivation. For instance, if one factor comprised four items, the average score refers to the average of these four incentive items. Since each item in the questionnaire was ranked on a five-point Likert scale, our measure for each motivation ranges between 1 and 5; the higher the number, the higher the importance attached to a specific motivation.

We used a number of control variables reflecting the characteristics of individual university researchers and their organizational environments. We aimed to control for individual experience and career-stage effects through the following variables: a) extent of previous involvement with industry, measured by number of joint publications with industry in the period 1995-2000, and average value of collaborative EPSRC grants (i.e. with industry) obtained by the researcher between 1995 and 2001; ${ }^{5}$ and b) researcher's age and academic status (i.e. whether the researcher is a professor or not). Our organization-level control variables include the impact of department size, the composition of departmental research funding, and research quality of the institution. Previous research shows that these organizational characteristics could have an impact on the extent to which researchers engage with industry (Belkhodja and Landry, 2007; Feldman et al., 2002; Schartinger et al., 2002; Tornquist and Kallsen, 1994). We considered the following variables: a) size of the department to which the researcher is affiliated (measured by average number of full-time equivalent staff for the period

\footnotetext{
${ }^{5}$ Both variables log transformed.
} 
1998/99-2000/01); b) volume of research funding at department level, including volume of research income from contracts with industry per member of staff, and volume of research income from public sources per member of staff over the same period (both indicators refer to the period 1998/99-2000/01); ${ }^{6}$ and c) departmental research quality proxied by the 2001 UK RAE rating. We use dummy variables to identify departments with the highest score $\left(5^{*}\right)$ and departments ranked lower than five, using point five as the reference category. ${ }^{7}$ Finally, we include scientific discipline and regional dummies to control for differences across scientific fields and geographic location in terms of researchers’ propensities to engage with industry. Some of information underpinning the control variables is from non-survey sources, such as records of previous collaborative grants, joint publications, or RAE research rankings, in order to alleviate some common method bias.

\subsection{Control for selection bias}

Only respondents reporting engagement with industry (1,088 individuals - 71\% of 1,528) were asked about their motivations. Because this risks introducing selection bias since we do not account for why researchers decide to engage with industry, we use a two-stage regression model, drawing on Manning et al. (1987). In the first stage, we ran a logit model with the dependent variable for whether a researcher engaged with industry or not. We included five control variables to capture perceived barriers to engaging with industry, and some individual and departmental features; information was available from all 1,528 respondents for all these variables. ${ }^{8}$

\footnotetext{
${ }^{6}$ Data on department finances and staff numbers are from www.hesa.ac.uk. Variables for industry and public research funding, and number of staff, were computed at department level as averages for the academic years 1998-99 and 2000-01. Public research funding refers to funding for research from any of the UK research councils. Finance data are in £’000. All variables log transformed.

${ }^{7}$ The choice of these three categories is based on the fact that the reference category accounts for a large proportion of departments: three categories produces a more even distribution of departments. Information on UK RAE 2001 is from: www.hero.ac.uk.

${ }^{8}$ The 5 variables related to barriers are dichotomous variables which take the value 1 if the respondent assessed the barriers as very, or extremely important. The 5 barriers are: absence of established
} 
From this model we calculated the predicted probability for each individual to engage with industry. We then ran a second stage model for individuals who engaged at least once, but controlled for selection bias by including the predicted probabilities of interaction from the first stage model (variable name: prob.). In the second stage, we used frequency of engagement in the various channels as defined above (section 3.3) as dependent variables, in ordered logit regressions.

\section{Results}

\subsection{Taxonomy of motivations for engaging with industry}

Table 1 presents descriptive results for the different incentive items, broken down by discipline, to indicate the proportion of respondents assessing an item as very or extremely important (i.e. scores of 4 or 5).

Insert Table 1 about here

Two issues emerged. First, there is significant variation in terms of which incentive items researchers deem to be important. While $74.5 \%$ of researchers rated 'applicability of research’ as highly important, only $11.1 \%$ rated ‘seeking IP rights’ similarly. Also, ‘access to personal income’ was considered important by only $16 \%$ of academics, indicating that pecuniary gains were far less significant than other reasons for working with industry.

Second, there was variation across disciplines, with some notable differences such as those between engineering, and chemistry, computer science, mathematics and physics. Across the engineering fields, there are few statistical differences in terms of incentives

procedures to collaborate with industry; nature of my research not aligned with industry interests or needs; potential conflicts with industry regarding royalty payments from patents or other IP rights; short term orientation of industry research; and rules and regulations imposed by university or government funding agency. The results of the first-stage logistic regressions are available on request. 
researchers ranked as important. ${ }^{9}$ Significantly fewer researchers in mathematics and chemistry, assessed items as important compared to the overall sample. Computer scientists and physicists occupied an intermediate position, since for approximately half of the items, proportions were not statistically different from those prevailing in the engineering fields.

A factor analysis conducted on the 12 items resulted in four factors (Table 2). The first comprises five items, all related to expectations related to learning opportunities from engagement with industry. We labelled this 'learning' motivation. The second factor, which we labelled 'access to in-kind resources', reflects keenness to access resources, such as materials, research expertise and equipment. The third factor is related to expectations about 'accessing funding' for research. The fourth factor, which we labelled ‘commercialization', reflects expectations of personal economic returns (PCA results are reported in Table A3 in the Appendix).

Insert Table 2 about here

A first evaluation of these results reveals that three motivations, i.e. learning, access toin-kind resources, and access to funding, are related to supporting academics' research and only commercialization is related to deriving economic benefit from the research. We look at the implications of this finding in the discussion section.

\subsection{Relationship between types of motivation and channels of interaction}

Having identified four independent motivations for academics to engage with industry, we conducted a regression analysis to examine the impact of these motivations on different channels of interactions.

\footnotetext{
${ }^{9}$ The two items where there were significant differences across engineering fields are: 'feedback from industry' and 'access to equipment'.
} 
Table 3 presents the results for the relationship between frequency of interaction via five channels, and researchers' ranking of the importance of the four motivations. We find that certain motivations have a distinct influence on the frequency of interactions across engagement channels. The learning motivation is positively associated with higher frequencies of industry engagement across several channels, i.e. joint research, contract research and consulting, all of which are based on relationships involving personal contacts with industry partners.

Insert Table 3 about here

Commercialization as a main motivation is positively associated with spin-off company activity, consulting and patenting, but shows no significant relationship with frequency of engagement in any of the other channels. Researchers who regard access to funding as particularly important engage more frequently in joint research, contract research and to some degree, consulting, although this last is only weakly significant. In contrast, high importance of access to in-kind resources has a negative effect on the frequency of engagement in contract research, consulting, spin-offs and patenting, and no significant impact on joint research.

Finally, with respect to our control variables, these results show that, ceteris paribus, experience in collaborative research increases the probability of more frequent collaboration via several channels. While being a professor has a positive impact on engagement frequency (with the exception of spin-off company activity), being a young researcher has a positive impact on the frequency of engagement in joint research and consulting. Researchers in lower-rated research departments tend to do more consulting compared to researchers in high ranked departments, while researchers in departments with higher ratios of per capita research income from industry are particularly likely to 
engage in more frequent contract research. We also found some variation across disciplines. For instance, while chemists are less likely to engage in contract research and consulting compared to mechanical engineers, they are more likely to patent. To confirm the robustness of our results, we conducted analyses using different constructions for the dependent variables. For instance, we devised dichotomous dependent variables and ran probit and logit regressions. The results are similar to those in Table 3. Also, since interaction via one channel may not be independent of activity via another, we conducted multivariate probit analysis to capture possible interdependencies among different channels, based on the STAT routine proposed by Cappellari and Jenkins (2003). Table A4 in the Appendix reports the results for the multivariate probit model, which are in line with those in Table 3.

As our information is drawn from a survey, the results do not provide ultimate answers about the direction of causation. However, conceptually, we would argue that it is more likely that motivation determines the frequency of engagement than vice versa.

\section{Discussion and implications}

In this paper, we investigate two questions: what motivates academics to engage with industry, and how do their motivations differ with respect to various ways of engaging with industry? We identified four main motivations: (i) commercialization (commercial exploitation of technology or knowledge); (ii) learning (informing academic research through engagement with industry); (iii) access to funding (complementing public research monies with funding from industry); and (iv) access to in-kind resources (using industry-provided equipment, materials and data for research).

Three of these factors are research-related; only one is related to an intention to be entrepreneurial. In fact, our results suggest that most academics engage with industry in order to further their own research, either through learning or through access to funds and other resources. In addition, commercialization on average was ranked lowest by 
our survey respondents (Appendix Table A2).

While the desire to raise funds for research is intuitively appealing, the learning motivation requires clarification. The items related to the 'learning' motivation refer to the expected benefits from gaining new insights, receiving feedback on research, and accessing new knowledge through engagement with industry. These benefits are likely to arise from an important yet often under-appreciated aspect of public research, i.e. backward linkages from applied technology. For instance, resolving problems that occur in technology development can lead to follow-on research activities, inform academic research agendas and in some cases even lead to new scientific disciplines (Rosenberg, 1982). Mansfield (1995) observes that the problems that many academics choose to work on are often inspired by their consulting activities. Also, a significant share of basic public research is associated with 'Pasteur's quadrant', i.e. is driven by the pursuit of basic understanding and considerations of use (Stokes, 1997). Much research in biotechnology, computer science, aeronautical engineering and other disciplines conforms to the Pasteur logic. It involves an intrinsic affinity between academic and industry research, which has implications for academics' motivations for choosing to interact with industry. Thus, whenever researchers engage in research that is driven by considerations of both basic understanding and use, the 'learning-based' logic for interaction is likely to be prevalent.

We also find that engagement in different forms of interaction is underpinned by varying motivations. Academics motivated by learning frequently engage in joint research, contract research and consulting, while motivations related to commercialization of research lead to engagement in activities such as patenting, spinoffs and consulting. It should be borne in mind, however, that patenting and involvement in spin-off companies are relatively rare compared to involvement in collaborative forms of interaction. Only around $15 \%$ of respondents participated in spin- 
off companies, and approximately 30\% of respondents reported filing patents.

The channels of engagement underpinned by research-related motivations, particularly learning and access to funding, are all based on direct collaboration with industry partners, which suggests that academic research interests benefit most from highly interactive, 'bench-level' relationships with industry users. The fact that 'access to inkind resources' is negatively related to most forms of interaction requires further comment. As joint research is not affected by this relationship, it appears that, particularly the more commercial forms of interaction, are rarely directly conducive to carrying out academic research. For instance, data derived from consultancy work or contract research may not be sufficiently novel for publication. However, these direct effects tend to be outweighed by indirect benefits, such as learning and access to research funding. Learning is an indirect benefit in that industry projects may not lead directly to novel scientific outputs, but may lead to new research problems and learning about new industrial applications (Perkmann and Walsh, 2009). Access to funding is also an indirect benefit as it may facilitate economies of scale and retention of staff at university laboratories.

It would appear from our results that there is a tension between commercialization and research-related motivations. While patenting and spin-off involvement are driven by commercialization, the more collaborative forms of interaction are driven by researchrelated motivations, but not commercialization. For patenting and spin-off involvement, our results confirm the basic premise of the entrepreneurial university. Academics engage in these activities because they are interested in deriving personal pay-offs from the commercialization of their knowledge and technologies. However, they do not appear to derive significant research-related benefits from this entrepreneurial behaviour. The reverse applies to collaborative forms of interaction: the motivations for joint research and contract research are clearly research-driven and commercialization 
plays no role.

Consulting is an exception to this pattern in that it is driven by both commercialization and research-related motivations. Consulting is 'polyvalent' as it allows academics to pursue personal income in an entrepreneurial manner (Louis et al., 1989), and to build personal relationships with industry practitioners and learn about industry problems and applications. Provision of consultancy, therefore, would be attractive for researchers who are driven by learning motivations (Mansfield, 1995; Murray, 2002). Thus, consulting may constitute the 'boundary' to university-industry collaboration (Lee, 1996) in the sense that it marks the limits to what constitutes research-relevant involvement with industry. So, while joint research, contract research and consulting are conducive to academic output, involvement in patenting and academic entrepreneurship may not generate similar complementarities with research.

One implication of our findings is that academics do not expect research-related benefits from patenting and spin-off activity. We can speculate on the reasons for the apparent lack of complementarity between commercialization and research-related objectives although our data do not allow us to be definitive. It could be that IP restrictions implicit in patenting and academic entrepreneurship may play a role. However, several studies confirm that the relationship between academic patenting and research productivity is generally positive (Baldini, 2008; Geuna and Nesta, 2006): academic researchers seem able to deal with confidentiality and IP protection issues and publication of their research (Murray, 2002). It is more likely that commercialization represents the laststage outcome in an ongoing process of research and therefore is not expected to contribute to the research. Many academics view patenting as a kind of 'side-effect' of their research (Agrawal and Henderson, 2002). As relatively few academic researchers patent their results, and even fewer establish spin-off companies, our main finding is that academics choose collaboration-intensive modes of interaction with industry in 
order to further their research activities.

More fundamental is that we do not find confirmation of a pervasive scenario in which entrepreneurial academics engage with industry to commercialize their research. Rather than a 'hybrid order' in which universities and industry converge to become common drivers of technological and economic development, most academic researchers appear keen to retain their autonomy by ensuring that collaborative work with industry is at least compatible with their research activity. This suggests that, at least for universities, the benefits of university-industry collaboration are best attained by cross-fertilization rather encouraging academics to become economic entrepreneurs. Collaboration is fruitful when it facilitates or contributes to both industry applications and academic research. Such collaboration retains the distinctiveness of the realms of scholarship and industry, but enables connection via interactive links that allow academic input to commercial problems and promotion of new ideas and new problems for university research (Rosenberg, 1982; Stokes, 1997). Announcements of the entrepreneurial university have often been premature and based on an overstated generalization of insights from the life sciences (see e.g. Owen-Smith and Powell, 2001). Our analysis of the physical and engineering sciences is a useful corrective in this respect.

In terms of policy, our results suggest a cautious approach to undifferentiated attempts to promote the entrepreneurial university. Many policy measures emphasize commercialization as the central mechanism for rendering university knowledge relevant to economy and society. These include the Bayh-Dole Act in the US and similar legislative initiatives in other countries, as well as governments' attempts to increase 'third stream engagement' in universities through subsidies for technology transfer offices (Czarnitzki et al., 2009; Mowery and Sampat, 2005). Data on disclosures, patenting, licensing and spin-offs are often used as metrics for assessing universities' technology transfer efforts. These types of policy measures are based on 
the principle that universities seek to protect their IP and exploit it in the industry market place. As the proceeds from the commercialization of IP are usually shared between the university and the individual academic inventor(s), the financial incentive is seen as encouraging academic involvement in technology transfer (Lach and Schankerman, 2008).

If, on the other hand, academics engage with industry mainly to further their research, then the focus on providing monetary incentives for commercialization appears misplaced. This is reinforced by the fact that the intention of policy-makers is not necessarily to maximize universities’ incomes, but rather to make technology available to firms and society at large. Also, universities' efforts to reap significant income from commercialization are generally unsuccessful as the proceeds from licensing are usually decimated by the costs of patenting and maintaining technology transfer offices (Thursby et al., 2001). Academics should not be offered incentives to patent or to be entrepreneurial per se; rather they should be encouraged to engage with industry more generally. As our results show, collaborative engagement with industry is often viewed by academics as beneficial to their research and, given that industry pays for much of this interaction, it could be assumed that industry partners also judge it to be useful (Gulbrandsen and Slipersæter, 2007). Policies privileging a narrow remit of technology transfer offices as champions of IP protection and incubators for spin-offs (Phan and Siegel, 2006) might be misaligned with most academics’ motivations for working with industry.

The data for our analysis are drawn from the physical and engineering sciences only. The life sciences are generally characterized by a high intensity of university-industry relationships (Powell et al., 1996) and responses from life science researchers could provide a different picture of the motivations underpinning IP transfer. However, as already mentioned, we believe that the large body of research on the life sciences has 
resulted in too much generalization of the results. Nevertheless, further research is needed to generate insights from other disciplines.

Another avenue for further research would be to examine the implications of different channels of interaction for the direction and quality of research conducted by academic researchers. Our results suggest that instances of university-industry collaboration should be viewed differentially in terms of judging their impact on academic research. If academics work with industry primarily to further their research, negative impacts on the direction of their research or on their research productivity arguably will be less likely. This holds particularly in the case that academics are motivated by learning and access to resources. Our data suggest that this type of collaboration is less likely to result in immediately, commercially relevant outputs, such as patents and spin-offs. At the same time, however, in the longer term, engagement in relationship-intensive collaboration with companies might enhance academic research output and generate university benefits via better research evaluations and higher levels of funding. Future research should seek to provide more informed judgement on the potential benefits and drawbacks associated with the different channels of engagement with industry used by academic researchers. 


\section{References}

Agrawal, A., Henderson, R. M., 2002. Putting patents in context: Exploring knowledge transfer from MIT. Management Science 48(1), 44-60.

Ambos, T. C., Mäkelä, K., Birkinshaw, J., D’Este, P., 2008. When does university research get commercialized? Creating ambidexterity in research institutions. Journal of Management Studies 45(8), 1424-1447.

Baldini, N., 2008. Negative effects of university patenting: Myths and grounded evidence. Scientometrics 75(2), 289-311.

Baldini, N., Grimaldi, R., Sobrero, M., 2007. To patent or not to patent? A survey of Italian inventors on motivations, incentives, and obstacles to university patenting. Scientometrics 70(2), 333-354.

Behrens, T. R., Gray, D. O., 2001. Unintended consequences of cooperative research: Impact of industry sponsorship on climate for academic freedom and other graduate student outcome. Research Policy 30(2), 179-199.

Belkhodja, O., Landry, R., 2007. The Triple-Helix collaboration: Why do researchers collaborate with industry and the government? What are the factors that influence the perceived barriers? Scientometrics 70(2), 301-332.

Bercovitz, J., Feldman, M., 2006. Entrepreneurial universities and technology transfer: A conceptual framework for understanding knowledge-based economic development. Journal of Technology Transfer 31(1), 175-188.

Bercovitz, J., Feldman, M., 2008. Academic entrepreneurs: Organizational change at the individual level. Organization Science 19(1), 69-89.

Blumenthal, D., Gluck, M., Louis, K. S., Stoto, M. A., Wise, D., 1986. Universityindustry research relationships in biotechnology - implications for the university. Science 232(4756), 1361-1366.

Bonaccorsi, A., Piccaluga, A., 1994. A theoretical framework for the evaluation of university-industry relationships. R\&D Management 24(3), 229-247.

Cappellari, L., Jenkins, S. P., 2003. Multivariate probit regression using simulated maximum likelihood. Stata Journal 3(3), 278-294.

Carayol, N., 2003. Objectives, agreements and matching in science-industry collaborations: Reassembling the pieces of the puzzle. Research Policy 32(6), 887-908.

Clark, B. R., 1998. Creating entrepreneurial universities: Organizational pathways of transformation. Pergamon, New York ; Oxford.

Cohen, W. M., Nelson, R. R., Walsh, J. P., 2002. Links and impacts: The influence of public research on industrial R\&D. Management Science 48(1), 1-23.

Czarnitzki, D., Glänzel, W., Hussinger, K., 2009. Heterogeneity of patenting activity and its implications for scientific research. Research Policy 38(1), 26-34.

D'Este, P., Patel, P., 2007. University-industry linkages in the UK: What are the factors determining the variety of interactions with industry? Research Policy 36(9), 1295-1313.

Etzkowitz, H., 1998. The norms of entrepreneurial science: Cognitive effects of the new university-industry linkages. Research Policy 27(8), 823-833.

Etzkowitz, H., 2003. Research groups as 'quasi-firms': the invention of the entrepreneurial university. Research Policy 32(1), 109-121.

Etzkowitz, H., Leydesdorff, L., 2000. The dynamics of innovation: From National Systems and "Mode 2" to a Triple Helix of university-industry-government relations. Research Policy 29(2), 109-123.

Feldman, M., Feller, I., Bercovitz, J., Burton, R., 2002. Equity and the technology transfer strategies of American research universities. Management Science 48(1), 105-121.

Feller, I., 1990. Universities as engines of R\&D-based economic growth: They think 
they can. Research Policy 19(4), 335-348.

Florida, R., Cohen, W. M., 1999. Engine or infrastructure? The university role in economic development, in: L. M. Branscomb, F. Kodama and R. Florida (Eds.), Industrializing knowledge: University-industry linkages in Japan and the United States. MIT Press, Massachusetts, pp. 589-610.

Geuna, A., Nesta, L. J. J., 2006. University patenting and its effects on academic research: The emerging European evidence. Research Policy 35(6), 790-807.

Glaser, B., Bero, L., 2005. Attitudes of academic and clinical researchers toward financial ties in research: A systematic review. Science and Engineering Ethics 11(4), 553-573.

Gulbrandsen, M., Slipersæter, S., 2007. The third mission and the entrepreneurial university model, in: A. Bonaccorsi and C. Daraio (Eds.), Universities and Strategic Knowledge Creation: Specialization and Performance in Europe. Edward Elgar, Cheltenham, pp. 112-143.

Hall, B. H., 2004. University-industry partnerships in the United States. European University Institute Working Paper ECO 2004/14, Firenze.

Jain, S., George, G., Maltarich, M., 2009. Academics or entrepreneurs? Investigating role identity modification of university scientists involved in commercial identity. Research Policy (in press).

Krimsky, S., 2003. Science in the private interest: Has the lure of profits corrupted the virtue of biomedical research? Rowman \& Littlefield, Lanham.

Lach, S., Schankerman, M., 2008. Incentives and invention in universities. RAND Journal of Economics 39(2), 403-433.

Lee, Y. S., 1996. 'Technology transfer' and the research university: A search for the boundaries of university-industry collaboration. Research Policy 25(6), 843-863.

Lee, Y. S., 2000. The sustainability of university-industry research collaboration: An empirical assessment. Journal of Technology Transfer 25(2), 111-133.

Louis, K. S., Blumenthal, D., Gluck, M., Stoto, M. A., 1989. Entrepreneurs in academe: An exploration of behaviors among life scientists. Administrative Science Quarterly 34(1), 110-131.

Lowe, R. A., 2006. Who develops a university invention? The impact of tacit knowledge and licensing policies. Journal of Technology Transfer 31(4), 415429.

Manning, W. G., Duan, N., Rogers, W. H., 1987. Monte Carlo evidence on the choice between sample selection and two-part models. Journal of Econometrics 35(1), 59-82.

Mansfield, E., 1995. Academic research underlying industrial innovations: Sources, characteristics, and financing. Review of Economics and Statistics 77(1), 55-65.

McKelvey, M., Holmén, M. (Eds.), 2009. Learning to compete in European universities: From social institution to knowledge business. Edward Elgar, Cheltenham.

Meyer-Krahmer, F., Schmoch, U., 1998. Science-based technologies: universityindustry interactions in four fields. Research Policy 27(8), 835-851.

Mintzberg, H., 1983. Structure in fives: Designing effective organizations, International edition. Prentice Hall, Upper Saddle River, NJ.

Moutinho, P., Fontes, M., Godinho, M., 2007. Do individual factors matter? A survey of scientists' patenting in Portuguese public research organisations. Scientometrics 70(2), 355-377.

Mowery, D. C., Nelson, R. R. (Eds.), 2004. Ivory tower and industrial innovation: University-industry technology before and after the Bayh-Dole Act. Stanford University Press, Stanford.

Mowery, D. C., Sampat, B. N., 2005. The Bayh-Dole Act of 1980 and universityindustry technology transfer: A model for other OECD governments? Journal of Technology Transfer 30(1/2), 115-127. 
Murray, F., 2002. Innovation as co-evolution of scientific and technological networks: Exploring tissue engineering. Research Policy 31(8,9), 1389-1403.

Nelson, R. R., 2001. Observations on the post-Bayh-Dole rise of patenting at American universities. Journal of Technology Transfer 26(1-2), 13-19.

Nelson, R. R., 2004. The market economy, and the scientific commons. Research Policy 33(3), 455-471.

Noble, D. F., 1977. America by design: Science, technology, and the rise of corporate capitalism. Knopf, New York.

Owen-Smith, J., 2003. From separate systems to a hybrid order: Accumulative advantage across public and private science at Research One universities. Research Policy 32(6), 1081-1104.

Owen-Smith, J., Powell, W. W., 2001. Careers and contradictions: Faculty responses to the transformation of knowledge and its uses in the life sciences. Research in the Sociology of Work 10, 109-140.

Owen-Smith, J., Powell, W. W., 2001. To patent or not: Faculty decisions and institutional success at technology transfer. Journal of Technology Transfer 26(1), 99-114.

Perkmann, M., Walsh, K., 2007. University-industry relationships and open innovation: Towards a research agenda. International Journal of Management Reviews 9(4), 259-280.

Perkmann, M., Walsh, K., 2008. Engaging the scholar: Three forms of academic consulting and their impact on universities and industry. Research Policy 37(10), 1884-1891.

Perkmann, M., Walsh, K., 2009. The two faces of collaboration: Impacts of universityindustry relations on public research. Industrial and Corporate Change (in press).

Phan, P. H., Siegel, D. S., 2006. The effectiveness of university technology transfer: Lessons learned from qualitative and quantitative research in the US and UK. Foundations and Trends in Entrepreneurship 2(2), 66-144.

Pirnay, F., Surlemont, B., Nlemvo, F., 2003. Toward a typology of university spin-offs. Small Business Economics 21(4), 355-369.

Powell, W. W., Koput, K. W., Smith-Doerr, L., 1996. Interorganizational collaboration and the locus of innovation: Networks of learning in biotechnology. Administrative Science Quarterly 41(1), 116-145.

Rosell, C., Agrawal, A., 2009. Have university knowledge flows narrowed? Evidence from patent data. Research Policy 38(1), 1-13.

Rosenberg, N., 1982. Inside the black box: Technology and economics. Cambridge University Press, Cambridge.

Schartinger, D., Rammer, C., Fischer, M. M., Fröhlich, J., 2002. Knowledge interactions between universities and industry in Austria: Sectoral patterns and determinants. Research Policy 31(3), 303-328.

Shane, S. A., 2004. Academic entrepreneurship: University spinoffs and wealth creation. Edward Elgar, Cheltenham.

Shane, S. A., 2005. Economic development through entrepreneurship: Government, university and business linkages. Edward Elgar, Cheltenham.

Siegel, D. S., Waldman, D., Link, A., 2003. Assessing the impact of organizational practices on the relative productivity of university technology transfer offices: An exploratory study. Research Policy 32(1), 27-48.

Siegel, D. S., Wright, M., Lockett, A., 2007. The rise of entrepreneurial activity at universities: Organizational and societal implications. Industrial and Corporate Change 16(4), 489-504.

Slaughter, S., Leslie, L. L., 1997. Academic capitalism: Politics, policies and the entrepreneurial university. Johns Hopkins University Press, Baltimore, MD.

Stephan, P. E., Levin, S. G., 1992. Striking the mother lode in science: The importance 
of age, place, and time. Oxford University Press, Oxford.

Stiglitz, J., Wallsten, S., 1999. Public-private technology partnerships: Promises and pitfalls. American Behavioural Scientist 43-73(1), 52-73.

Stokes, D. E., 1997. Pasteur's quadrant: Basic science and technological innovation. Brookings Institution Press, Washington, D.C.

Thursby, J. G. A., Jensen, R. A., Thursby, M. C. A., 2001. Objectives, characteristics and outcomes of university licensing: A survey of major US universities. Journal of Technology Transfer 26(1), 59-72.

Tornquist, K. M., Kallsen, L. A., 1994. Out of the ivory tower: Characteristics of institutions meeting the research needs of industry. Journal of Higher Education 65(5),

Vallas, S. P., Kleinman, L., 2008. Contradiction, convergence and the knowledge economy: The confluence of academic and commercial biotechnology. SocioEconomic Review 6(2), 283 - 311.

Zerhouni, E., 2003. The NIH Roadmap. Science 302(5642), 63-72.

Zucker, L. G., Darby, M. R., Brewer, M. B., 1998. Intellectual human capital and the birth of US biotechnology enterprises. American Economic Review 88(1), 290.

Zuckerman, H., Merton, R. K., 1972. Age, aging, and age structure in science, in: M. W. Riley, M. Johnson and A. Foner (Eds.), A Sociology of Age Stratification, New York: Russell Sage Foundation. Russell Sage Foundation, New York, pp. 292356. 


\section{Tables and Figures}

Table 1. Proportion of respondents who assessed incentive items as very or extremely important (4 or 5 on five-point Likert scale)

\begin{tabular}{|c|c|c|c|c|c|c|c|c|c|c|c|}
\hline & CHNG & CHEM & CIVG & COMP & ELEC & GENG & MATH & MENG & MANG & PHYS & Total \\
\hline 1. Applicability of research & 71.9 & 64.9 & 72.2 & 78.5 & 78.8 & 79.0 & 68.8 & 80.7 & 80.0 & 73.1 & 74.5 \\
\hline 2. Research Income from industry & 75.9 & 79.3 & 79.5 & 65.1 & 80.6 & 71.4 & 54.8 & 76.5 & 79.0 & 69.9 & 74.4 \\
\hline 3. Research Income from Gov. & 71.4 & 58.6 & 76.8 & 75.0 & 79.0 & 76.5 & 62.9 & 75.8 & 80.0 & 61.2 & 70.8 \\
\hline 4. Information on industry problem & 77.2 & 53.7 & 79.5 & 65.7 & 70.3 & 75.3 & 66.2 & 78.9 & 70.5 & 54.8 & 67.8 \\
\hline 5. Feedback from industry & 42.1 & 44.2 & 62.0 & 53.3 & 67.1 & 58.6 & 36.5 & 58.0 & 49.2 & 46.2 & 52.7 \\
\hline 6. Information on industry research & 41.1 & 36.3 & 50.7 & 41.3 & 52.1 & 45.5 & 32.8 & 51.6 & 52.5 & 47.1 & 45.0 \\
\hline 7. Access to materials & 43.1 & 30.8 & 50.0 & 41.5 & 48.6 & 43.9 & 20.6 & 45.7 & 47.5 & 43.1 & 41.2 \\
\hline 8. Becoming part of a network & 42.6 & 29.9 & 45.8 & 24.5 & 33.6 & 38.3 & 27.4 & 41.9 & 38.6 & 32.7 & 34.8 \\
\hline 9. Access to research expertise & 34.5 & 29.6 & 22.2 & 31.4 & 35.4 & 30.6 & 22.6 & 34.8 & 33.9 & 35.0 & 31.5 \\
\hline 10. Access to equipment & 19.3 & 22.2 & 18.3 & 10.4 & 35.7 & 25.5 & 9.7 & 23.0 & 15.5 & 25.2 & 22.0 \\
\hline 11. Source of personal income & 17.2 & 12.2 & 15.5 & 31.1 & 15.7 & 11.1 & 26.2 & 11.2 & 15.3 & 15.8 & 16.1 \\
\hline 12. Seeking IPR & 8.8 & 13.3 & 10.0 & 5.8 & 11.3 & 12.4 & 3.2 & 9.9 & 5.2 & 21.6 & 11.0 \\
\hline Number of observations* & 58 & 209 & 73 & 107 & 146 & 100 & 66 & 163 & 62 & 104 & 1088 \\
\hline
\end{tabular}

Notes: Abbreviations: CHNG, Chemical Engineering; CHEM, Chemistry; CIVG; Civil Engineering; COMP, Computer Science; ELEC, Electrical and Electronic Engineering; GENG, General Engineering; MATH, Mathematics; MENG, Mechanical, Aeronautical and Manufacturing Engineering, MANG; Materials and Metallurgy; PHYS, Physics.

* The total number of observations slightly varies across items due to missing responses. 
Table 2: Summary of factor analysis results

\begin{tabular}{lc}
\hline Motivational items & \multicolumn{1}{c}{ Motivation } \\
\hline Source of personal income & Commercialization \\
Seeking IPRs & \\
\hline Information on industry problems & \\
Feedback from industry & Learning \\
Information on industry research & \\
Applicability of research & \\
Becoming part of a network & \\
Access to materials & \\
Access to research expertise & Access to in-kind resources \\
Access to equipment & \\
Research income from industry & Access to funding \\
Research income from Gov. & \\
\hline
\end{tabular}


Table 3.Relationship between frequency of interaction and motivations

Ordered Logistic Regressions. Dependent variables: frequency of engagement in five channels

\begin{tabular}{|c|c|c|c|c|c|}
\hline & $\begin{array}{c}\text { Joint } \\
\text { Research }\end{array}$ & $\begin{array}{l}\text { Contract } \\
\text { Research }\end{array}$ & Consulting & Spin-offs & Patents \\
\hline Commercialization & $\begin{array}{c}0.020 \\
(0.074)\end{array}$ & $\begin{array}{c}0.042 \\
(0.071)\end{array}$ & $\begin{array}{c}0.559 * * * \\
(0.077)\end{array}$ & $\begin{array}{c}0.488 * * * \\
(0.102)\end{array}$ & $\begin{array}{c}0.758 * * * \\
(0.087)\end{array}$ \\
\hline Learning & $\begin{array}{c}0.265 * * * \\
(0.088)\end{array}$ & $\begin{array}{c}0.276 \text { *** } \\
(0.093)\end{array}$ & $\begin{array}{c}0.177 * \\
(0.094)\end{array}$ & $\begin{array}{c}0.197 \\
(0.139)\end{array}$ & $\begin{array}{l}-0.019 \\
(0.109)\end{array}$ \\
\hline Funding Resources & $\begin{array}{c}0.129 * \\
(0.068)\end{array}$ & $\begin{array}{c}0.299 * * * \\
(0.076)\end{array}$ & $\begin{array}{c}0.133 * \\
(0.075)\end{array}$ & $\begin{array}{c}0.039 \\
(0.106)\end{array}$ & $\begin{array}{c}0.037 \\
(0.092)\end{array}$ \\
\hline In-kind Resources & $\begin{array}{c}0.091 \\
(0.068)\end{array}$ & $\begin{array}{c}-0.231 * * * \\
(0.071)\end{array}$ & $\begin{array}{c}-0.196 * * \\
(0.077)\end{array}$ & $\begin{array}{c}-0.349 * * * \\
(0.108)\end{array}$ & $\begin{array}{c}-0.204 * * \\
(0.085)\end{array}$ \\
\hline N. Joint publ. (ln) & $\begin{array}{c}0.102 \\
(0.099)\end{array}$ & $\begin{array}{c}0.178 * \\
(0.098)\end{array}$ & $\begin{array}{c}0.083 \\
(0.098)\end{array}$ & $\begin{array}{c}0.275 * * \\
(0.130)\end{array}$ & $\begin{array}{c}0.195 * \\
(0.107)\end{array}$ \\
\hline N. Collab. Gr. (ln) & $\begin{array}{c}0.059 * \\
(0.033)\end{array}$ & $\begin{array}{c}0.041 \\
(0.033)\end{array}$ & $\begin{array}{c}0.059 * \\
(0.034)\end{array}$ & $\begin{array}{c}0.099 * * \\
(0.047)\end{array}$ & $\begin{array}{c}0.032 \\
(0.037)\end{array}$ \\
\hline Age & $\begin{array}{c}-0.021 * * \\
(0.009)\end{array}$ & $\begin{array}{l}-0.003 \\
(0.009)\end{array}$ & $\begin{array}{c}-0.018 * * \\
(0.008)\end{array}$ & $\begin{array}{c}0.009 \\
(0.012)\end{array}$ & $\begin{array}{c}0.007 \\
(0.010)\end{array}$ \\
\hline Professor status & $\begin{array}{c}0.581 \text { *** } \\
(0.183)\end{array}$ & $\begin{array}{c}0.441 * * \\
(0.177)\end{array}$ & $\begin{array}{c}0.438 * * \\
(0.173)\end{array}$ & $\begin{array}{c}0.407 * \\
(0.243)\end{array}$ & $\begin{array}{c}0.291 \\
(0.205)\end{array}$ \\
\hline Industry inc/staff (ln) & $\begin{array}{c}0.164 \\
(0.126)\end{array}$ & $\begin{array}{c}0.305 * * \\
(0.122)\end{array}$ & $\begin{array}{l}-0.088 \\
(0.134)\end{array}$ & $\begin{array}{c}0.064 \\
(0.175)\end{array}$ & $\begin{array}{c}0.227 \\
(0.149)\end{array}$ \\
\hline Public inc/staff (ln) & $\begin{array}{c}-0.234 * \\
(0.141)\end{array}$ & $\begin{array}{c}0.122 \\
(0.142)\end{array}$ & $\begin{array}{l}-0.039 \\
(0.162)\end{array}$ & $\begin{array}{l}-0.097 \\
(0.216)\end{array}$ & $\begin{array}{c}0.299 * \\
(0.181)\end{array}$ \\
\hline Dept. staff (ln) & $\begin{array}{c}0.027 \\
(0.139)\end{array}$ & $\begin{array}{c}0.129 \\
(0.144)\end{array}$ & $\begin{array}{c}0.192 \\
(0.154)\end{array}$ & $\begin{array}{c}0.025 \\
(0.187)\end{array}$ & $\begin{array}{c}0.005 \\
(0.165)\end{array}$ \\
\hline RAE 2001 Low & $\begin{array}{l}-0.037 \\
(0.179)\end{array}$ & $\begin{array}{c}0.276 \\
(0.183)\end{array}$ & $\begin{array}{c}0.363 * * \\
(0.185)\end{array}$ & $\begin{array}{l}-0.077 \\
(0.267)\end{array}$ & $\begin{array}{c}0.149 \\
(0.210)\end{array}$ \\
\hline RAE 2001 High & $\begin{array}{l}-0.085 \\
(0.182)\end{array}$ & $\begin{array}{l}-0.052 \\
(0.191)\end{array}$ & $\begin{array}{c}0.163 \\
(0.195)\end{array}$ & $\begin{array}{c}0.119 \\
(0.269)\end{array}$ & $\begin{array}{l}-0.119 \\
(0.223)\end{array}$ \\
\hline Chemistry & --- & $\begin{array}{c}-0.644 * * * \\
(0.242)\end{array}$ & $\begin{array}{c}-0.681 * * * \\
(0.251)\end{array}$ & --- & $\begin{array}{c}0.799 * * * \\
(0.285)\end{array}$ \\
\hline Civil Engineering & $\begin{array}{c}-0.717 * * * \\
\quad(0.278)\end{array}$ & --- & --- & --- & --- \\
\hline Computer Science & --- & $\begin{array}{c}-1.223 * * * \\
(0.296)\end{array}$ & $\begin{array}{c}-1.482 * * * \\
(0.332)\end{array}$ & --- & --- \\
\hline Electric \& Electronic Eng. & --- & --- & $\begin{array}{c}-0.995 * * * \\
(0.255)\end{array}$ & --- & $\begin{array}{c}0.909 * * * \\
(0.296)\end{array}$ \\
\hline General Engineering & --- & $\begin{array}{c}-0.641 * * \\
(0.271)\end{array}$ & --- & --- & $\begin{array}{c}0.669 * * \\
(0.321)\end{array}$ \\
\hline Mathematics & $\begin{array}{c}-0.849 * * \\
(0.399)\end{array}$ & --- & --- & --- & --- \\
\hline Physics & --- & $\begin{array}{c}-0.747 * * \\
(0.369)\end{array}$ & $\begin{array}{c}-0.976 * * \\
(0.387)\end{array}$ & --- & --- \\
\hline Prob. & $\begin{array}{c}0.688 \\
(0.584)\end{array}$ & $\begin{array}{c}0.505 \\
(0.573)\end{array}$ & $\begin{array}{c}1.439 * * \\
(0.579)\end{array}$ & $\begin{array}{l}-0.298 \\
(0.849)\end{array}$ & $\begin{array}{c}1.435 * * \\
(0.677)\end{array}$ \\
\hline Threshold / Cut point 1 & 0.986 & $2.393 * *$ & $2.745 * * *$ & $3.444 * * *$ & $5.418 * * *$ \\
\hline Region dummies & Included & Included & Included & Included & Included \\
\hline Number of observations & 960 & 964 & 966 & 964 & 959 \\
\hline Log Likelihood & -918.2 & -902.0 & -870.9 & -469.7 & -671.6 \\
\hline Restricted Log Likelihood & -973.3 & -991.6 & -975.9 & -511.4 & -765.6 \\
\hline Pseudo R ${ }^{2}$ Nagelkerke & 0.13 & 0.19 & 0.23 & 0.13 & 0.22 \\
\hline
\end{tabular}

Note: Two tailed t-test: $* \mathrm{p}<0.10$; ** $\mathrm{p}<0.05$; *** $\mathrm{p}<0.01$. Robust standard errors between brackets. For discipline dummy variables, only significant coefficients are shown in the table. 
Appendix

Table A1: Descriptive statistics for dependent variables

\begin{tabular}{|c|c|c|c|c|c|c|c|c|}
\hline Dependent Variables & Average & $\begin{array}{l}\text { St. } \\
\text { Dev. }\end{array}$ & Min. & Max. & $\begin{array}{l}\text { \% Observations } \\
\text { Category '0' }\end{array}$ & $\begin{array}{c}\text { \% Obs. } \\
\text { Category ' } 1 \text { ' }\end{array}$ & $\begin{array}{c}\text { \% Obs. } \\
\text { Category '2' }\end{array}$ & $\begin{array}{c}\text { Number } \\
\text { valid Obs. }\end{array}$ \\
\hline 1. Joint Research & 0.79 & 0.70 & 0 & 2 & 37.2 & 47.1 & 15.8 & 1079 \\
\hline 2. Contract Res. & 0.85 & 0.70 & 0 & 2 & 33.5 & 48.5 & 18.1 & 1085 \\
\hline 3. Consulting & 0.68 & 0.71 & 0 & 2 & 46.6 & 38.8 & 14.6 & 1087 \\
\hline 4. Spin-offs & 0.19 & 0.43 & 0 & 2 & 82.9 & 15.3 & 1.8 & 1085 \\
\hline 5. Patenting & 0.29 & 0.56 & 0 & 2 & 68.9 & 23.7 & 7.4 & 1079 \\
\hline
\end{tabular}


Table A2: Descriptive statistics and correlation matrix for explanatory and control variables

\begin{tabular}{|c|c|c|c|c|c|c|c|c|c|c|c|c|c|c|c|c|}
\hline & Ave. & St. Dev. & Min. & Max. & 1 & 2 & 3 & 4 & 5 & 6 & 7 & 8 & 9 & 10 & 11 & 12 \\
\hline 1. Commercialization & 2.04 & 0.91 & 1 & 5 & & & & & & & & & & & & \\
\hline 2. Learning & 3.50 & 0.85 & 1 & 5 & 0.24 & & & & & & & & & & & \\
\hline 3.Funding resources & 3.97 & 0.94 & 1 & 5 & 0.13 & 0.28 & & & & & & & & & & \\
\hline 4. In-kind resources & 2.78 & 1.06 & 1 & 5 & 0.19 & 0.48 & 0.22 & & & & & & & & & \\
\hline 5. Ln Joint Pub & 0.52 & 0.73 & 0.0 & 3.81 & 0.01 & 0.02 & 0.11 & 0.04 & & & & & & & & \\
\hline 6. Ln Coll. Grant & 2.86 & 2.47 & 0.0 & 7.60 & 0.02 & 0.06 & 0.15 & 0.09 & 0.07 & & & & & & & \\
\hline 7. Age & 45.9 & 9.86 & 27 & 75 & -0.05 & 0.04 & 0.05 & -0.01 & 0.16 & 0.27 & & & & & & \\
\hline 8. Professor & 0.53 & 0.50 & 0.0 & 1 & -0.02 & -0.02 & 0.09 & -0.03 & 0.22 & 0.26 & 0.59 & & & & & \\
\hline 9. Indu. Inc./staff & 1.61 & 0.78 & 0.0 & 3.53 & -0.04 & 0.05 & 0.13 & 0.02 & 0.12 & 0.11 & 0.01 & -0.01 & & & & \\
\hline 10. Pub. Inc./staff & 2.61 & 0.70 & 0.0 & 4.33 & -0.01 & -0.08 & -0.01 & 0.02 & 0.14 & 0.11 & -0.01 & 0.05 & 0.34 & & & \\
\hline 11. Ln Staff & 4.22 & 0.68 & 2.07 & 5.53 & 0.01 & -0.04 & -0.02 & 0.01 & 0.09 & 0.07 & 0.01 & 0.02 & 0.42 & 0.37 & & \\
\hline 12. Low RAE & 0.31 & 0.46 & 0 & 1 & 0.02 & 0.07 & 0.07 & 0.02 & -0.04 & -0.09 & -0.01 & -0.06 & -0.12 & -0.36 & -0.41 & \\
\hline 13. High RAE & 0.30 & 0.46 & 0 & 1 & -0.01 & -0.05 & -0.03 & 0.01 & 0.07 & 0.08 & 0.06 & 0.07 & 0.20 & 0.36 & 0.43 & -0.43 \\
\hline
\end{tabular}

Correlation coefficients significant at the 0.05 level, in bold. 
Table A3: Factor analysis results: Incentives for interacting with industry

\begin{tabular}{|c|c|c|c|c|c|c|}
\hline & Mean & St. Dev. & Factor 1 & Factor 2 & Factor 3 & Factor 4 \\
\hline Source of personal income & 2.04 & 1.25 & -0.032 & -0.079 & -0.001 & 0.896 \\
\hline Seeking IPRs & 2.05 & 1.11 & 0.324 & 0.340 & 0.105 & 0.521 \\
\hline Information on industry problems & 3.87 & 1.07 & 0.800 & 0.079 & 0.160 & -0.033 \\
\hline Feedback from industry & 3.41 & 1.19 & 0.721 & 0.220 & 0.080 & 0.081 \\
\hline Information on industry research & 3.26 & 1.21 & 0.656 & 0.303 & 0.216 & 0.012 \\
\hline Applicability of research & 3.99 & 1.05 & 0.764 & 0.044 & -0.015 & 0.075 \\
\hline Becoming part of a network & 2.94 & 1.21 & 0.625 & 0.288 & 0.016 & 0.064 \\
\hline Research income from industry & 4.01 & 1.12 & 0.064 & -0.001 & 0.831 & 0.178 \\
\hline Research income from government & 3.93 & 1.16 & 0.159 & 0.172 & 0.772 & -0.121 \\
\hline Access to materials & 3.03 & 1.35 & 0.193 & 0.735 & 0.047 & 0.020 \\
\hline Access to research expertise & 2.83 & 1.23 & 0.254 & 0.812 & 0.011 & -0.036 \\
\hline Access to equipment & 2.48 & 1.48 & 0.127 & 0.821 & 0.155 & 0.082 \\
\hline \multicolumn{3}{|l|}{ Rotation sums of squared loadings } & 2.82 & 2.26 & 1.40 & 1.15 \\
\hline \multicolumn{3}{|c|}{ Proportion of variance explained (\%) } & 23.48 & 18.81 & 11.69 & 9.55 \\
\hline \multicolumn{3}{|c|}{ Cumulative proportion of variance explained (\%) } & 23.48 & 42.29 & 53.98 & 63.53 \\
\hline
\end{tabular}


Table A4: Relationship between frequency of interaction and motivations

Results of multivariate probit analysis. Dependent variables are dichotomous taking the value of 1 if the degree of engagement is above the median for a given engagement channel (and 0 otherwise)

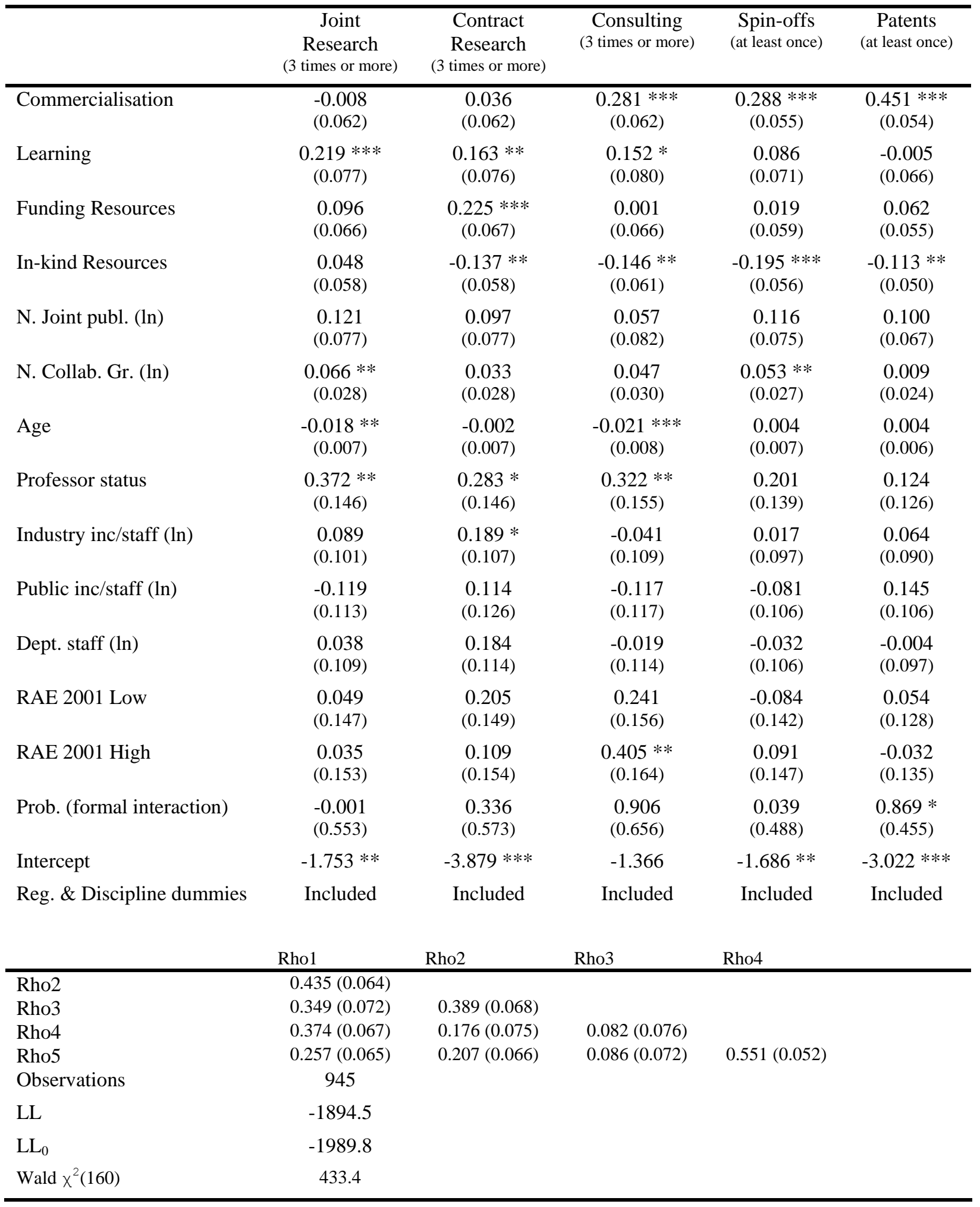

Note: Two tailed t-test: * $\mathrm{p}<0.10$; ** $\mathrm{p}<0.05$; *** $\mathrm{p}<0.01$. Standard errors between brackets. All regressions include discipline dummies. 
